\title{
NORBERT ELIAS E A TEORIA DOS PROCESSOS CIVILIZADORES
}

\author{
Célio Juvenal Costa ${ }^{1}$ \\ Sezinando Luiz Menezes ${ }^{2}$
}

\section{RESUMO}

Discorremos, neste artigo, sobre a vida e a teoria de Norbert Elias. Sociólogo alemão, viveu entre os anos de 1897 e 1990, escreveu vários livros, dos quais os mais conhecidos são os dois volumes de $O$ Processo Civilizador, em que apresentou a sua teoria dos processos civilizadores. Elias escreveu seus primeiros livros no final da década de 30 do século XX, mas foi somente nos anos 70 que sua obra se tornou efetivamente conhecida e seu nome se inscreveu no rol dos grandes pensadores sociais da atualidade. Dividimos o artigo em quatro partes: na primeira apresentamos uma breve biografia de Norbert Elias; na segunda discorremos sobre os conceitos de Sociologia, História, Sociedade e Indivíduo, presentes em sua teoria, os quais são, a nosso ver, fundamentais para entender o seu pensamento; na terceira parte fazemos a apresentação dos conceitos de Processo Civilizador e de Sociedade de Corte, procurando mostrar a sua concepção acerca da formação da sociedade contemporânea; e, finalmente, na última parte procuramos estabelecer uma relação entre a teoria de Elias e a História da Educação, objetivando mostrar que tal teoria pode servir como um aporte teórico fundamental para as pesquisas histórico-educacionais. Trata-se, fundamentalmente, de um artigo que se propõe ser introdutório ao pensamento de Norbert Elias, o pensando, especialmente, como um intelectual das ciências sociais e, portanto, da Educação.

Palavras-chave: Norbert Elias; Processo Civilizador; Sociedade de Corte; História da Educação.

\section{NORBERT ELIAS AND THEORY OF CIVILIZING PROCESSES}

\begin{abstract}
In this article, we speak about life and the theory of Norbert Elias. German sociologist, lived between the years 1897 and 1990, wrote several books of which the best known are the two volumes of the Civilizing Process, presenting his theory of civilizing processes. Elias wrote his first books in the late 20th century 30 years, but it was only in the 70 years that his work became effectively known and his name enrolled on the list of major social thinkers of today. Split the article into four parts: the first presents a brief biography of Norbert Elias; in the second we speak the concepts of Sociology, History, Society and Individual, present in his theory, which are, in our view, essential to understand your thinking; in the third part we do the presentation of concepts of Civilizing Process and Court Society, seeking to show their design about the formation of contemporary society; and finally the last part we try to establish a relationship between the theory of Elias and the History of Education, aiming to show that such a theory might serve as a fundamental theoretical contribution to the historical and educational research. This is, fundamentally, an article that purports to be the introductory thought of Norbert Elias, the thinking, especially as an intellectual of the social sciences and, therefore, of education.

Keywords: Norbert Elias; Civilizing Process; Court Society; History of Education.
\end{abstract}


Os homens, sabemos, não são unívocos; ao contrário dos

livros, não se pode esperar que não apresentem contradições. (Norbert Elias)

\section{Começando...}

Num sentido scricto seria precipitação considerar Norbert Elias um intelectual da educação, pois seus escritos não revelam uma preocupação específica com a instituição escola ou mesmo com uma filosofia da educação. No entanto, num sentido lato é possível, sim, trata-lo como um pensador que pode e deve ser estudado e utilizado pelo campo da educação, especialmente com a história e a sociologia da educação, pois sua teoria e seus estudos acabam por contribuir com a explicação do fenômeno educativo.

Elias se define como sociólogo; mais especificamente, defende a concepção de uma sociologia configuracional, em que substitui o conceito de sociedade pelo de configuração social, que é uma rede de interdependências entre as pessoas e grupos. Mas, apesar de se definir como sociólogo, ele rompe com a ideia de que o objeto da sociologia é somente o presente, especialmente quando defende, por exemplo, que o estudo da sociedade de corte absolutista deveria ser, também, sociológico.

Para colocar o passado como objeto de estudo sociólogo, Norbert Elias aponta a necessidade de que a sociologia e a história trabalhem juntas, propondo a criação de uma nova ciência, que teria como base uma teoria histórico-sociológica ou uma sociologia histórica. Assim, sua teoria dos processos civilizadores requer não somente o aporte da sociologia, mas, também, da história e, neste sentido, os estudos elisianos se tornam uma ferramenta para a compreensão histórica do fenômeno educativo. Renato Janine Ribeiro, na apresentação que faz da edição brasileira do primeiro volume de O Processo Civilizador, aponta que Elias procura, com o livro, responder o seguinte como "os homens se tornaram educados e começaram a tratar-se com boas maneiras?", partindo de um pressuposto muito caro particularmente à história da educação, de que "não existe atitude natural no homem" (ELIAS, 1994a, p. 9).

Para apresentar algumas linhas sobre o pensamento de Elias, necessário se faz algumas escolhas em termos da bibliografia a ser utilizada. Como o objetivo aqui é estabelecer uma relação da teoria elisiana como o campo da Educação, particularmente com o campo da História da Educação, a escolha recaiu nos dois volumes de O Processo Civilizador e na Sociedade de Corte, livros que apresentam a base da teoria dos processos civilizadores em meio ao estudo, que se estende pelos três livros, da formação e das características da moderna corte europeia. Além disso, para traçar a biografia de Elias e se aprofundar na sua teoria trabalhamos com uma obra que contém suas memórias, Elias por ele mesmo, na forma de entrevista e de pequenos ensaios.

\section{Elias - uma breve biografia}

Norbert Elias nasceu na cidade de Breslau em 22 de junho de 1897. Hoje a cidade pertence à Polônia e se chama Wroclaw, mas durante muito tempo pertencia a Alemanha. Filho único de uma família judia-alemã de classe média, Elias cresceu em meio aos livros, tendo começado "a ler muito cedo, mergulhava em todo o tipo de livro. Nessa época eu também devia ter seis ou sete anos" (ELIAS, 2001a, p. 11). Seu pai era do ramo têxtil e tinha uma empresa que empregava, na época do seu nascimento, em torno de trinta pessoas. Sua mãe era dona de casa, encarregando-se de gerir a casa e os compromissos sociais do casal. Mais tarde, na época nazista, seus pais foram perseguidos e seu pai 
morreu em 1940 e, logo depois, sua mãe desapareceu em Auschwitz. Elias foi filho único e nunca se casou ou teve filhos.

Elias relata que sua carreira de professor e pesquisador foi despertada logo na adolescência, para a qual "trabalhei tenazmente para atingir esse objetivo, mesmo que às vezes me parecesse impossível" (ELIAS, 2001a, p. 22). Elias estudou no Liceu de Breslau até os 18 anos, quando foi convocado para a guerra, a Primeira Guerra Mundial, na qual participava de um grupo especializado em assegurar o funcionamento das linhas de telefone e telégrafo que ligavam as trincheiras ao quartel-general. Portanto, mesmo sendo soldado numa guerra brutal, Elias relata que nunca matou um inimigo.

Acabada a guerra, Elias se matriculou na faculdade, ainda em Breslau, em 1918. Estudou Medicina e Filosofia de forma concomitante. Esclarece: "Escolhi a medicina antes de tudo porque era desejo de meu pai, mas também porque achava aquilo interessante. Minha inclinação pela filosofia fora estimulada desde o liceu" (ELIAS, 2001a, p. 37). Ele se formou nas duas faculdades, abandonando, depois, o exercício da medicina e fez seu doutorado em filosofia, obtendo o título de doutor em 1924. Como teve que fazer estudos de psicologia para o desenvolvimento de sua tese, Elias também se tornou doutor em psicologia.

Quanto à medicina, Elias (2001a, p. 99) mostra que, mais tarde, percebeu a importância desses estudos para a sua concepção de sociologia:

Só mais tarde percebi com clareza que o estudo da medicina fora uma das experiências fundamentais que me estimularam a abandonar a filosofia para me consagrar à sociologia. Mas até os anos 60, quando dava minhas aulas de introdução a alunos de sociologia, tinha às vezes ao alcance da mão um crânio humano desmontável. Parecia-me que um estudante de sociologia devia ter algumas noções essenciais da estrutura do sistema nervoso humano para ser capaz de se aproximar da concepção do homem indispensável à compreensão de contextos sociais, ou seja, uma concepção de homem como fundamentalmente organizado para viver em meio a homens, animais, plantas e minerais.

Quanto ao doutorado em filosofia, o título obtido, doutor, não credenciou Elias para o direito de ensinar na universidade. Para isso, ele teria que desenvolver outro trabalho e defende-lo como tese de habilitação, o que não ocorreu por desentendimentos sérios que teve com seu orientador da tese por conta da sua discordância acerca conhecimentos $a$ priori, tão característicos da filosofia kantiana. Rompeu, então, com a filosofia, por acreditar que ela não se constituiria como uma verdadeira ciência social e passou a dedicar-se aos estudos sociológicos. Convém lembrar, no entanto, que na época, década de 1920 (e mais algum tempo depois), a sociologia enquanto ciência autônoma ainda era inexistente.

Depois de dois anos trabalhando em uma fábrica de fornos de fundição, por conta de problemas financeiros na família em virtude da alta da inflação no período pós-guerra, Elias se mudou para Heidelberg, uma cidade universitária por excelência, onde se iniciou, de fato, em seus estudos sociológicos.

Passei então para a sociologia, e, em Heidelberg, só tinha contato com sociólogos, e não mais com filósofos. Encontrei então Mannheim, que não era muito mais velho que eu; gostamos um do outro e nos tornamos bons amigos. Mannheim, quanto a isso não há a menor dúvida, era um homem brilhante e estava em seu apogeu na época; atraía então cada vez 
mais estudantes, que abandonavam os professores mais velhos, como Alfred Weber. (ELIAS, 2001a, p. 42)

Foi em Heidelberg que Elias teve contato com alguns dos principais sociólogos alemães, dentre eles, Karl Mannheim (1893-1947) e Alfred Weber (1868-1958), o primeiro ligado ao marxismo e o segundo filiado a um pensamento mais liberal e irmão de Max Weber (1864-1920), o qual havia falecido havia pouco. Elias foi introduzido no círculo social dos intelectuais por meio de Mannheim que o apresentou a Marianne Weber (18701954), viúva de Max Weber e que recebia em sua casa a nata intelectual de Heidelberg, ao mesmo tempo que tornava os novatos conhecidos. Foi nessa cidade que Elias teve contato com a obra de Marx, "que nunca lera antes" (ELIAS, 2001a, p. 43). O objetivo de Elias naquela cidade era se tornar um Privat-dozent - professor com currículo livre na universidade alemã e que era remunerado diretamente pelos alunos - de sociologia.

Elias estava, então, em uma universidade em que os estudos sociológicos reuniam muitos professores e estudantes:

\begin{abstract}
Naquela época, Heidelberg era uma espécie de meca da sociologia. $\mathrm{O}$ grande Max Weber morrera, é verdade, mas sua viúva ainda vivia, e seu irmão Alfred igualmente, ele também professor de sociologia. De maneira geral, a Alemanha já tinha nessa época uma tradição sociológica bastante respeitável; pensem em Simmel [1858-1918], que só obteve um lugar como professor pouco antes de sua morte, porque era judeu. Havia três ou quatro personagens célebres, como por exemplo Leopold von Wiese [1876-1969]. O florescimento da sociologia começou portanto desde a época imperial, mas acentuou-se de fato apenas depois de 1918. (ELIAS, 2001a, p. 44)
\end{abstract}

Ao mesmo tempo em que mergulhava nos novos estudos sociológicos, Elias relata que já começava, embrionariamente, a fazer a crítica ao que ele chamava de ideologização das teorias sociais, à medida que elas estavam comprometidas com doutrinas políticas, tanto de direita como de esquerda. Assim, ainda embrionariamente, ele passou a objetivar, em sua vida como cientista, a busca de um padrão que fosse realmente científico para a sociologia. "Meus estudos de biologia - relata Elias (2001a, p. 46) - de química e de física me davam uma idéia muito precisa da ciência, e o que encontrei depois na sociologia estava em total contradição com isso". Era preciso erguer o véu que escamoteia os conceitos marcados por ideologias e, para isso, a sociologia se tornou muito útil, "porque ela acenava com a possibilidade desse desvelamento" (idem), contribuindo com aquilo que ele havia definido como sua missão de vida: "desmistificar as ocultações. [...] mas por meio do trabalho sobre um saber a respeito da sociedade, um trabalho que fosse realista. Foi o que havia decidido fazer; e foi o que efetivamente tentei." (idem, p. 47).

Ainda em Heidelberg, Elias dedicou-se ao estudo de dois temas, os quais serviram para ele entrar no rol dos jovens intelectuais daquela cidade universitária. O primeiro foi sobre arquitetura gótica, procurando relacioná-la ao desenvolvimento das cidades, pois na Alemanha da época "toda cidade queria um campanário mais alto que sua vizinha, e havia uma enorme concorrência entre as diversas cidades" (ELIAS, 2001a, p. 49), relacionando a arte ao poder. O segundo estudo, que lhe rendeu uma viagem a Florença, na Itália, foi uma análise sociológica sobre a passagem do pensamento pré-científico para o pensamento científico, pois considerava que a cidade italiana havia sido o centro daquela evolução. $\mathrm{O}$ segundo estudo se circunscrevia na crítica às ciências sociais: 
Em sociologia, essa ainda é minha convicção, somos sempre bloqueados na fase pré-científica, e foi o motivo de eu ter me ocupado com essa guinada: como eles conseguiram no início do século XV [a renascença florentina] representar um espaço tridimensional - quer dizer, a realidade - em uma tela de duas dimensões? (Idem, p. 50)

Norbert Elias ficou em Heidelberg até 1930, tendo-se mudado para Frankfurt onde se tornou, até 1935, assistente de Karl Mannheim, que havia conseguido uma cátedra de Sociologia na universidade. Elias relata que acompanhou Mannheim tanto pela amizade e pelo respeito que lhe dedicava, quanto pela possibilidade de obter a licença para ser professor - promessa feita pelo próprio Mannheim - e, assim, poder ser Privat-dozent. Como não conseguiu obter a licença Elias sai da Alemanha, na tentativa de conseguir algum posto como docente universitário. Primeiramente ele vai para a Suíça e, depois, ainda em 1935, para Paris. Da época em que esteve em Frankfurt Elias escreve a primeira versão de um dos seus livros mais conhecidos, a Sociedade de Corte.

Elias ficou pouco tempo em Paris, pois não obteve êxito em lecionar na universidade. Viveu do dinheiro que seu pai mandava e das vendas de uma pequena fábrica de brinquedos que montou com um amigo. Durante sua estada em Paris ele teve os primeiros trabalhos publicados: um estudo sobre o estilo kitsch e outro sobre a expulsão dos huguenotes da França.

Ainda em 1935 Elias vai para a Inglaterra, onde fixa residência até 1975. Quase metade da vida do sociólogo alemão se passou na Inglaterra e, por isso, ele afirmou que não se sentia nem alemão e nem inglês e, sim, europeu.

Sua primeira fase em terras inglesas foi em Londres, na qual recebeu uma bolsa de um comitê de refugiados judeus, "o suficiente para que não morresse de fome e pagasse um pequeno quarto" (ELIAS, 2001a, p. 62). O dinheiro que recebia estava condicionado à escrita de um livro, que veio a ser seu escrito mais famoso, os dois volumes de $O$ Processo Civilizador. Durante três anos, de 1935 a 1938, fazendo pesquisa na biblioteca do Museu Britânico, Elias dedicou-se exclusivamente ao seu livro, e ao escrevê-lo na Inglaterra, comparando as mentalidades nacionais da Alemanha e da França, Elias relata que foi isso o fez "vislumbrar pela primeira vez a descoberta que acho mais importante que fiz, ou seja, que só se pode descobrir a estrutura das sociedades comparando-as de maneira sistemática" (idem, p. 66). O sucesso do Processo Civilizador só veio mais tarde, pois, publicado pela primeira vez em 1939, a tiragem inicial foi quase um fracasso: "quando visitei - informa Elias - o editor depois da guerra [1945], ele me disse: 'Veja, está entulhado no porão. Não poderíamos leiloá-los? Ninguém quer comprá-los'.” (idem, p. $71)$.

Elias ficou em Londres até 1954, período em que trabalhou na formação para adultos. Naquele ano ele foi contratado pela Universidade de Leicester para lecionar sociologia. Organizou um curso de introdução aos estudos sociológicos e criou, também, o departamento de Sociologia, iniciativa que rendeu frutos à medida que, depois de Londres, aquela universidade foi uma das principais fornecedoras de professores de sociologia de toda Inglaterra. Durante sua estada em Leicester, no entanto, Elias teve dificuldade de emplacar seu método, pois muitos assistentes consideram sua posição como sendo marginal, pois o "fato de pensar em termos de processo de longa duração ainda não estava na moda, em sociologia" (ELIAS, 2001a, p. 75).

De 1962 a 1964 Norbert Elias vai para Acra, capital de Gana, ocupar a cadeira de Sociologia na universidade local. O contato com uma cultura diferente, apesar de a universidade lá se pautar pelos modelos de Oxford e Cambridge, foi muito importante para 
ele. A experiência de ver in vivo ritos mágicos, sacrifícios de animais e outras coisas de uma cultura diferente da europeia, foi, para Elias, indispensável.

De volta para a Europa, Elias conheceu o sucesso em sua carreira. Retornou para Leicester e até 1984 foi, também, professor convidado na Holanda, em Amsterdã e Haia, e na Alemanha, em Münster, Constanz, Aix-la-Chapelle, Frankfurt, Bochum e Bielefeld. A partir de 1975 passa a dividir sua vida entre Amsterdã e o Centro de Pesquisas Interdisciplinares de Bielefeld. Em 1977 Elias recebe uma honrosa homenagem ao receber o Prêmio Adorno, da cidade de Frankfurt, pelo conjunto de sua obra.

Para terminar esta sintética biografia de Norbert Elias e para estabelecer um nexo com o que vai ser apresentado do seu pensamento, vejamos, primeiro, como ele se define como homem e como profissional e como entende a ética do cientista:

Deveria haver mais gente como eu que não tem medo do que descobre. Evidentemente, os homens acreditam que vão ter surpresas desagradáveis caso reflitam sobre si próprios com uma pitada de realismo. Peguem Freud: à sua maneira, pretendia descobrir as coisas tais como eram realmente, independentemente do que as pessoas pudessem ter dito antes. Eis a missão de um cientista, tanto nas ciências sociais como nas ciências da natureza. É isso a ética de um cientista. (ELIAS, 2001a, p. 57)

E, segundo, sobre sua relação, sempre difícil, com o que, na academia, passa a ser modelo, passa a ser moda:

Sim, eu tinha essa certeza [de que o que tinha a dizer era importante], mesmo quando nadava contra a corrente, contra todos aqueles que detinham um poder. Se há uma coisa que considero positiva em mim é o fato de jamais ter me deixado corromper pelas modas, quaisquer que fossem. Nunca me autorizei dizer algo sob o pretexto de que era moda. (ELIAS, 2001a, p. 84)

O que preocupava Elias eram os problemas dos homens, afirmando que "efetivamente escrevi em algum lugar 'Os mortos não têm problemas"” (ELIAS, 2001a, p. 88). Elias morreu em 1990 na cidade de Amsterdã.

\section{Conceitos da teoria: sociologia, história, sociedade e indivíduo}

Quando passou a ter contato com os estudos sociológicos, Norbert Elias procedeu, pouco a pouco, a crítica às concepções em voga em sua época - críticas que trataremos sucintamente mais a frente - e foi delineando aquilo que seria, no seu entendimento, o verdadeiro objeto da sociologia, bem como qual deveria ser a missão do sociólogo. Para ele, tratava-se de conceber uma teoria que fosse empiricamente comprovável; o que considerava trabalho para uma vida toda:

Foi pouco a pouco que compreendi essa missão, de maneira ainda bastante vaga durante minha temporada em Heidelberg, depois de modo mais nítido em Frankfurt. Ela consistia em elaborar uma teoria central da sociologia que fosse empírica, ou seja, verificável e emendável, em vez de fundar as bases de uma teoria sobre as quais as gerações futuras pudessem construir, ou mesmo rejeitar, corrigir e desenvolver. Mergulhei nessa consciência cada vez mais aguda de meus objetivos e trabalho nisso 
até hoje, entremeado às numerosas tarefas particulares que realizei ao longo de minha vida. (ELIAS, 2001a, p. 145)

Este aspecto da teoria elisiana parece ser fulcral, à medida que ela serve de crivo para inúmeras críticas realizadas por Elias no que diz respeito, basicamente, à cientificidade da sociologia, pois "faltam teorias empiricamente baseadas para explicar o tipo de mudanças sociais de longo prazo que assumem a forma de processo e, acima de tudo, de desenvolvimento" (ELIAS, 1994a, p. 216).

A falta de bases empíricas para as teorias sociológicas acaba por torná-las especulativas e parciais em suas análises. Os dados empíricos, advindos da pesquisa cuidadosa e criteriosa das formas como a sociedade se expressa, garantem, para Elias, uma sociologia que não seja dogmática, pois os próprios dados podem ser comprovados e, se for o caso, refutados. A análise recai nos "processos sociais em geral" e no "desenvolvimento social em particular" (ELIAS, 1994a, p. 217). Os dados com os quais o cientista social trabalha para estudar a sociedade e seus inúmeros mecanismos e manutenção devem estar isentos de ideologia, pois, do contrário, os próprios dados empíricos são escolhidos crivados por uma doutrina e, portanto, tornam-se parciais.

A crítica da ideologia iniciada por Mannheim foi assumida por Elias, mas com um propósito construtivo, diferente de seu professor $^{3}$, pois se tratava de um passo a mais em direção a uma teoria da sociedade que mostrasse que há tanto saberes que mascaram a realidade como saberes que a desvelam. A sociologia não-científica é aquela que serve a uma ideologia e, mesmo afirmando o contrário, acaba por mascarar o real. "O saber de um médico sobre o corpo humano, saber que pode curar, não deriva da ideologia", afirma Elias, e, depois, se pergunta: "Por que não se poderia produzir um saber sobre a sociedade humana que não fosse ideológico?" (ELIAS, 2001a, p. 122).

As ideologias estão geralmente ligadas a perspectivas políticas e, como tais, acabam, para Elias, por se configurar como doutrinas e não como ciência. A ligação efetiva - e afetiva - a doutrinas políticas e, em certos casos, a doutrinas partidárias, faz do pesquisador um ser comprometido, de antemão, como um projeto igualmente político. Elias, escrevendo suas memórias na década de 1980, deixa claro que sua teoria se pretendia desvinculada de doutrinas políticas:

A teoria do processo civilizador e da formação do Estado, a teoria simbólica do saber e das ciências e, num sentido mais amplo, a teoria do processo e da figuração, que eu empenhei em elaborar, não são marxistas, liberais, socialistas ou conservadoras. As doutrinas partidárias ocultas, os ideais sociais mascarados pelo véu da ciência parecem-me falsificações; acho-as, além disso, estéreis. Era - e ainda é sem dúvida uma das razões que explicam as dificuldades colocadas por essas teorias e as obras que as contêm. (ELIAS, 2001a, p. 148)

$\mathrm{O}$ procedimento do pesquisador requerido pela teoria elisiana requer do pesquisador o distanciamento, isto é, reconhecer a si próprio como um ser entre outros seres humanos e reconhecer a sociedade como uma figuração social, que é constituída por indivíduos que se relacionam de forma interdependente e que são "tributários e dependentes uns dos outros". Para isso, Elias chama a atenção para algo fundamental em sua teoria, a não separação entre indivíduo e sociedade; o distanciamento possibilita a superação intelectual da polarização entre indivíduo e sociedade, possibilita a compreensão de que qualquer dos polos, se privilegiados, acaba por mascarar a realidade: "Eis um 
objetivo tão fácil como ovo-de-colombo e tão difícil como a revolução copernicana." (ELIAS, 2001a, p. 149).

Elias fornece um exemplo de como, em sua opinião, as análises sociais comprometidas com projetos políticos e econômicos acabam por falsear a realidade. $\mathrm{O}$ exemplo, na época em que escreveu suas memórias, era candente, pois afetava praticamente o mundo todo, e, de certa forma, continua atual:

\begin{abstract}
Essas duas formas de sociedade, a capitalista e a comunista, permaneciam na realidade absolutamente imperfeitas. Ambas funcionavam possivelmente melhor do que a maioria das sociedades nos estágios de desenvolvimento precedentes, mas a desigualdade social e a miséria mantiveram-se em nível elevado. Em ambos os casos, a realidade ficava muito atrás da imagem idealizadora das ideologias com as quais estas buscavam legitimar-se a seus próprios olhos e em suas relações. Simplificando, pode-se dizer que a Rússia ainda estava longe de ser um país de homens iguais e que a América ainda estava longe de ser um país de homens livres. (ELIAS, 2001a, p. 160)
\end{abstract}

Tanto a crítica à ideologização das ciências sociais como a crítica à especulação não-empírica, tem por base a concepção da relação entre indivíduo e sociedade. Elias afirma que teorias sociológicas e históricas concebem tais conceitos de forma separada, o que acarreta pensamentos que colocam ou a primazia do indivíduo na compreensão da sociedade, ou a primazia do social. Ao fazer, por exemplo, a crítica a Parsons ${ }^{4}$, de que ele tratava sociedade e indivíduo como se fossem dois corpos separados, Elias defende a ideia de que as estruturas sociais e de personalidade perfazem, necessariamente, uma interrelação indissolúvel (1994b, p. 235); o individual e o social, na teoria elisiana, são dois aspectos do mesmo ser humano.

Para Elias, o ser humano é o único animal que já é dotado de uma aparelhagem biológica que o permite ter uma natureza social. "O aprendizado infantil da linguagem por exemplo - é possibilitado pelo entrelaçamento de dois processos: um processo biológico de maturação e um processo social de aprendizagem" (ELIAS, 2009, p. 29). A própria face humana, aponta Elias, já é biologicamente determinada a indicar que se trata de um ser que é, por natureza, social:

A face humana, comparada à face dos macacos, é, como foi, prova viva do maior papel desempenhado, comparado aos movimentos corporais, que os componentes comportamentais faciais assumiram na vida grupal humana. A característica inata de tais sinais indica, uma vez mais, que no caso humano natureza e sociedade estão estreitamente inter-relacionados. (ELIAS, 2009, p. 42-43)

Elias debate com a ideologia que concebe o homem como homo clausus, conceito que se encontra já n'O processo civilizador e em outros textos seus da maturidade, inclusive em suas memórias. O homo clausus é a ideia de um indivíduo "absolutamente autônomo e portanto absolutamente livre" (ELIAS, 1994a, p. 150), que constitui a ideologia burguesa atual e que ocupa um lugar bem definido nas teorias sociais contemporâneas. É, segundo ele, a utopia ou o ideal do homem livre, especialmente dos determinismos sociais; e, se é uma teoria ideológica utópica, não tem correspondente com a realidade e, portanto, não contribui para o seu entendimento, muito ao contrário. $\mathrm{O}$ autodistanciamento retro referido requer o abandono dessa utopia, pois o próprio pesquisador, comprometido com a doutrina, se concebe livre e acima da sociedade. É Revista HISTEDBR On-line, Campinas, $n^{o}$ 53, p. 238-262, out2013-ISSN: 1676-2584 245 
preciso abandonar, em prol do conhecimento da sociedade, a concepção monística do homo clausus:

\begin{abstract}
Enquanto não se executa esse procedimento, vê-se a si mesmo sempre e involuntariamente como um indivíduo isolado face à sociedade; vê-se a si mesmo, portanto, face a todos os outros homens enquanto "indivíduo" se situando para além da sociedade, ou, ao contrário, vê-se a sociedade como existindo para além do indivíduo e fora dele. Enquanto não se recorrer ao procedimento do autodistanciamento, enquanto não se for capaz de dominá-lo pelo pensamento, será difícil, para resumir, fazer navegar o navio da sociologia, assim como o das ciências humanas em geral, entre as ideologias do individualismo e do coletivismo. (ELIAS, 2001a, p. 149)
\end{abstract}

Para Norbert Elias, portanto, a perspectiva social deve levar em consideração a não separação entre indivíduo e sociedade, tratando ambos conceitos como se fossem dois aspectos interrelacionados da trama social. Os dois conceitos devem ser considerados de tal maneira que "sejam levados a se referirem a processos" (ELIAS, 1994a, p. 239). O processo social é entendido como movimento social, no qual os indivíduos se interpenetram de tal modo que só é possível definir o ser humano como indivíduo social, em todos os momentos da vida, seja coletiva ou particular. Os fenômenos de grupo, afirma Elias (2001a, p. 73), têm certas particularidades que são diferentes e distintivas daqueles fenômenos individuais (como o caso, por exemplo, das terapias de grupo e terapias individuais), mas sempre "é preciso considerar os dois níveis simultaneamente".

Outro aspecto da teoria elisiana que estabelece conexão com os apresentados aqui é sobre a relação entre sociologia e história. Como relata em suas memórias (1994a, p. 112), o seu interesse, desde a época de Heidelberg, se concentra na "organização singular dos processos de longa duração e sua diferença em relação às leis na natureza física concebidas como espécie de módulo da história da humanidade". É a história em processo que ele defende. Neste sentido, se explica seu interesse, manifestado em seus três primeiros livros, pelo estudo da Sociedade de Corte na Europa.

Partindo de uma crítica tanto da sociologia quando da história, em Sociedade de Corte, Elias mostra a necessidade de que as duas ciências sociais sejam articuladas de tal maneira que se alcance uma "coordenação frutífera entre a pesquisa histórica e sociológica" (2001b, p. 51). A crítica reside no fato de que, para ele, à sociologia somente interessa as figurações sociais, sem os indivíduos, e à história somente os indivíduos, sem as figurações. Para se romper os limites de ambas as ciências, Elias propõe a existência de uma teoria histórico-sociológica ou de uma sociologia histórica. Para tanto, três aspectos problemáticos relacionados às duas ciências devem ser levados em consideração para superar a dicotomia. Em primeiro lugar tanto uma quanto outra ciência ao estudar o passado acabam, geralmente, julgando-o pelos padrões do presente; os padrões e princípios ideológicos, éticos, culturais etc. do presente do pesquisador influenciam sua análise, acabando por cobrar do passado aquilo em que ele justamente se afasta do presente e, por conseguinte, tal perspectiva não contribui para o entendimento de relações sociais idas ${ }^{5}$. $\mathrm{O}$ segundo ponto diz respeito à ideia de que na história existe a possibilidade da liberdade ou do determinismo absolutos, na qual a pesquisa histórica acaba por reivindicar a liberdade absoluta do indivíduo e a pesquisa sociológica reivindica, por sua vez, a predominância absoluta da sociedade sobre o indivíduo; tal abordagem "também evidencia mais claramente, ao mesmo tempo, o caráter extracientífico e ideológico da idéia de que uma pesquisa histórica, dirigida para fenômenos individuais, é o porta-estandarte da liberdade 
humana, enquanto a sociologia, por sua vez dirigida para fenômenos sociais, é o portaestandarte do determinismo" (ELIAS, 2001b, p. 56). O terceiro e último ponto diz respeito ao fato de que as perspectivas histórica e sociológica, enquanto ciências particulares e sem conexão uma com a outra, não contribuem para a continuidade de pesquisas, sendo que a união das duas possibilitaria assegurar o seu progresso contínuo.

Elias não propõe a união da sociologia com a história e vice-versa, e nem o desaparecimento de ambas enquanto ciências particulares. Cada uma tem a sua perspectiva e o seu, digamos, campo de atuação específico. O problema, para ele, é que as ambas as ciências acabam por ser reducionistas, pois ao privilegiar uma parte do social, o indivíduo ou a sociedade, dão autonomia ao que, de fato, não é independente. As ferramentas das duas ciências, em seu conjunto, na sociologia histórica ou na história sociológica, possibilitariam uma verdadeira visão de conjunto e, mais do que isso, uma integração, um estudo que leve em conta que indivíduo e sociedade são inseparáveis e interdependentes. A sociologia histórica teria como seu "objeto" de estudo justamente o indivíduo social. E, como esse indivíduo social se constrói e muda num processo de longa duração, a perspectiva histórico-sociológica teria como tarefa explicar exatamente tal processo.

Como estamos vendo, o fundamento das críticas e das propostas de Elias reside na sua compreensão de que indivíduo e sociedade não podem sem pensados de forma separada. Aí reside, também, a base para sua compreensão da sociedade como configuração social, como uma rede de interdependências, e a definição de sua teoria como Sociologia Configuracional.

A imagem de homem como "personalidade fechada" é substituída aqui pela "personalidade aberta", que possui um maior ou menor grau (mas nunca absoluto ou total) de autonomia face de outras pessoas e que, na realidade, durante toda a vida é fundamentalmente orientada para outras pessoas e dependente delas. A rede de interdependências entre os seres humanos é o que os liga. Elas formam o nexo do que aqui é chamado de configuração, ou seja, uma estrutura de pessoas mutuamente orientadas e dependentes. Uma vez que as pessoas são mais ou menos dependentes entre si, inicialmente por ação da natureza e mais tarde através da aprendizagem social, da educação, socialização e necessidades recíprocas socialmente geradas, elas existem, poderíamos nos arriscar a dizer, apenas como pluralidades, apenas como configurações. Este o motivo por que, conforme afirmado antes, não é particularmente frutífero conceber os homens à imagem do homem individual. Muito mais apropriado será conjecturar a imagem de numerosas pessoas interdependentes formando configurações (isto é, grupos ou sociedades de tipos diferentes) entre si. (ELIAS, 1994a, p. 240)

Para explicar didaticamente em que consiste a teoria da sociedade como configuração, Elias utiliza da metáfora da dança (ELIAS, 1994a, p. 250). A dança existe enquanto definição, enquanto técnica, enquanto arte, portanto, existe enquanto uma ideia, mas, de fato, ela só existe enquanto tal somente quando dois indivíduos dançam; a partir daí, eles não são mais indivíduos isolados e se definem como um par, sendo somente aí que, de fato, a dança se concretiza.

A relação social entre os homens, compreendida como configuração, permite, para Elias, entender o passado também como uma rede de interdependências e, assim, ligarmos o presente ao passado e, nesse processo, compreendermo-nos a nós próprios. Pesquisar os processos de longa duração, na perspectiva de procurar ver neles figurações sociais, faz com que reproduzamos a identidade última de todos os indivíduos e, com isso, podemos 
estabelecer relações de proximidade (de nos enxergarmos em) com todas as sociedades do passado, inclusive aquelas que, aos olhos do presente, parecem mais bárbaras. Há diferenças, é claro, entre as figurações sociais no tempo histórico, mas o fato de serem figurações (insistindo, de serem redes de interdependências) faz com que haja uma identidade no ser humano. Por isso, para Elias, estudar a Sociedade de Corte é, em última instância, compreender o presente. E mais: "Assim, alcançamos um outro plano, no qual a alteridade das outras sociedades e dos indivíduos que as constituem não é sentida como estranha ou extravagante, e no qual os indivíduos e outras sociedades se tornam reconhecíveis e compreensíveis como pessoas semelhantes a nós mesmos" (ELIAS, 2001b, p. 215).

Dentre as várias questões que podem ser estudadas nas figurações do passado como nas do presente, a principal delas, para Elias, são as relações de poder. Nas redes de interdependências que configuram os indivíduos há uma série de poderes, de alcances mais reduzidos e mais longos, aos quais os seres particulares estão sujeitos ou sujeitam outros. O poder, na teoria elisiana, não é somente econômico ou político ou de outra vertente mais comumente estudada; ele, o poder, está no centro das inúmeras relações humanas. "Sem definição e sem explicação das relações de poder no seio de um grupo, os grupos de macrossociologia ou de microssociologia permanecem incompletos, vagos e finalmente estéreis. As transformações das relações de poder e sua explicação pedem uma atenção toda especial." (ELIAS, 2001a, p. 154).

As reflexões conceituais de Elias visando à formatação de uma teoria sociológica eficiente por si mesma se iniciaram, como vimos, já na sua estada em Heidelberg e se cristalizaram, pela primeira vez, em seus primeiros livros (A Sociedade de Corte e $\mathrm{O}$ Processo Civilizador). Uma ciência social que se aplique, de fato, ao desvelamento da sociedade, que libere "o saber humano do anátema dos sociólogos relativistas e materialistas econômicos, de um lado, e nominalistas filosóficos, de outro, lançaram sobre ele", encontrou resistências ao longo da vida de Norbert Elias, resistências ideológicas, conceituais, políticas, mas, talvez a principal delas tenha sido, paradoxalmente, a própria institucionalização da sociologia como ciência particular:

Mas a profissionalização e o caráter institucional da sociologia - cujas vantagens práticas ninguém contesta e que, em razão do lugar atual das ciências humanas nas universidades, são inevitáveis - acarretaram, ao mesmo tempo um estreitamento da perspectiva sociológica, assim como um certo estiolamento da imaginação e da sensibilidade sociológicas. (ELIAS, 2001a, p. 144)

Elias defende a ideia de que com o avanço no desenvolvimento da autonomia e do reconhecimento da sociologia como uma ciência social específica e com a definição do campo sociológico e dos respectivos limites da atuação do sociólogo, as distâncias para com a história aumentaram e a perspectiva do estudo das figurações sociais num processo de longa duração diminuíram drasticamente. A sociologia se ocupa prioritariamente do presente e a história do passado, mesmo levando em consideração estudos sociológicos que pesquisam o passado das sociedades presentes e da perspectiva da história do tempo presente.

Terminemos esta breve apresentação do que consideramos conceitos fundamentais para o entendimento da teoria elisiana e passemos, agora, a considerar aspectos de sua análise da Sociedade de Corte e do Processo Civilizatório.

\section{O PROCESSO CIVILIZADOR E A SOCIEDADE DE CORTE}


Logo no início do volume primeiro d'O Processo Civilizador, Norbert Elias indaga, como, ainda, questões abertas nas ciências sociais, como se deu realmente a mudança na sociedade moderna, como ocorreu o processo civilizador no Ocidente, em que consistiu e quais foram as forças motivadoras ou as causas desse processo, sendo que a intenção do seu livro é, justamente, "contribuir para a solução dessas principais questões." (1994a, p. 13). E, para responder as perguntas formuladas parte do princípio de que é na formação do chamado estado absolutista que se encontra a origem do processo civilizador ocidental.

Elias não utiliza o conceito de civilização como qualitativamente superior ao chamado incivilizado, mas, apenas para estabelecer uma distinção, ressaltando as características de comportamentos sociais e individuais, de boas-maneiras, de educação do corpo e dos hábitos (controle dos instintos ou das pulsões), que são distintas de outros povos anteriores à modernidade europeia, especialmente, as características feudais. Ou seja, para Elias, "civilização" é a denominação atribuída aos comportamentos que moldaram a configuração da sociedade ocidental contemporânea. "O processo civilizador não segue uma linha reta" (1994a, p. 185), alerta Elias, como é o caso, por exemplo, das Guerras Mundiais ou, mesmo, dos trajes de banho que as mulheres passaram a usar em público, quando houve um relaxamento do controle social, no entanto, apesar disso, é possível, para ele, falar de uma tendência para todos os tipos de comportamento.

A conclusão de uma fase fundamental do processo civilizador no Ocidente ocorreu, segundo Elias, quando a burguesia passou a dirigir as nações europeias, pois, com ela, a noção do civilizado como superior passou a existir na percepção europeia em relação a outros povos, estendo-se, daí, para praticamente o mundo todo.

[...] uma fase fundamental no processo civilizador foi concluída no exato momento em que a consciência de civilização, a consciência de superioridade de seu próprio comportamento [da burguesia] e sua corporificação na ciência, tecnologia ou arte começaram a se espraiar por todas as nações do Ocidente. (ELIAS, 1994a, p. 64)

Elias parte da verificação que o conceito de civilização, vastamente utilizado a partir do século XIX, que inclusive se apresenta como qualidade distintiva do Ocidente com relação a outros povos, tem sua origem na palavra francesa civilité e relaciona-se, diretamente, à formação da Sociedade de Corte europeia. Civilité, de palavra torna-se conceito explicativo e auto-identitário. Esse processo teve início - "seu ponto de partida pode ser determinado com exatidão" (ELIAS, 1994a, p. 65) - com Erasmo de Roterdã a partir da publicação do seu De civilitate morum puerilium (Da civilidade em crianças), obra que veio à luz em 1530 e que, segundo Elias, tratou de um tema que estava já maduro para a época. A rápida circulação do livro de Erasmo reflete como o tema foi ao encontro de necessidades sociais já estabelecidas: "Ainda durante a vida de Erasmo - isto é, nos primeiros seis anos após a publicação - teve mais de 30 reedições. No conjunto, houve mais de 130 edições, 13 das quais em data tão recente como o século XVIII." (idem, p. 6566).

Civilidade, civilização e civilizador são conceitos que expressaram o desenvolvimento do que Elias chama de sociedade monopolizada, que se inicia com a Sociedade de Corte, e que ganhou novas feições com a burguesia, a qual refinou a existência dos monopólios, de estatais para supranacionais. A história ocidental recente é marcada pela formação de órgãos centrais de forte estabilidade e especialização em grandes regiões do planeta, sendo que tal formação foi devidamente acompanhada por um processo de "mudança na conduta de sentimentos humanos rumo a uma direção muito 
específica" (idem, p. 193), e tal mudança é o que caracteriza, segundo Elias, o processo civilizador. Mas a mudança, individual e social, não é nem racional, como deliberação proposital, e nem irracional, como se fosse incompreensível; a mudança não "constitui uma mera sequência de mudanças caóticas e não-estruturadas" (idem, p. 104). O processo civilizador não foi nem natural e nem intencionalmente planejado ${ }^{6}$.

O processo civilizador tem, para Elias, dois momentos que são, na verdade, duas faces da mesma moeda: as mudanças sociais, que caracterizam-se, basicamente, pela existência e refinamento de monopólios, e as mudanças individuais, que representam as mudanças ocorridas na concepção do próprio indivíduo; sem, no entanto, cair na "armadilha" de entender a sociedade de forma separada do indivíduo. Ambos os processos ocorrem mediante lutas, mais gerais e/ou mais particulares. No caso do indivíduo, o processo civilizador se caracterizou pela mudança no campo de batalha do homem medieval, que envolvia sempre o outro e, portanto, a luta física contra o outro, para, na sociedade atual, a luta interna do indivíduo, luta instilada pela criação do superego, luta, enfim, que, segundo Elias, nem sempre chega a um bom desfecho.

\begin{abstract}
Mas, ao mesmo tempo, o campo de batalha foi, em certo sentido, transportado para dentro do indivíduo. Parte das tensões e paixões que antes eram liberadas diretamente na luta de um homem com outro terá agora que ser elaborada no interior do ser humano. As limitações mais pacíficas a ele impostas por outras relações com outros homens espelham-se dentro dele; um padrão individualizado de hábitos semiautomáticos se estabeleceu e consolidou nele, um 'superego' específico que se esforça por controlar, transformar ou suprimir-lhe as emoções de conformidade com a estrutura social. Mas os impulsos, os sentimentos apaixonados que não podem mais manifestar-se diretamente nas relações entre pessoas frequentemente lutam, não menos violentamente, dentro delas contra essa parte supervisora de si mesma ${ }^{7}$. (ELIAS, 1994b, p. 203)
\end{abstract}

No caso, ainda, do processo civilizador individual, Elias aponta que há casos em que ele é bem-sucedido e casos em que é mal-sucedido, dependendo de como o sujeito adulto resolve, internamente, a relação entre controle e desejo. No entanto, os casos mal ou bem sucedidos pertencem, ainda para Elias (1994b, p. 206), à extremidade da escala, pois "a maioria das pessoas civilizadas vive um meio-termo entre os dois extremos. Aspectos socialmente positivos, tendências pessoalmente gratificantes e frustradoras, misturam-se em proporções variadas" $"$.

As mudanças ocorridas tanto no âmbito social como no individual que caracterizam a contemporaneidade têm sua origem, na visão de Elias, na processo de formação da Sociedade de Corte e, numa perspectiva de história de longa duração, o processo civilizador instaurado na passagem do Medievo para o Moderno é o que explica a atualidade. Neste sentido, aí reside a importância teórica de se compreender a formação da Sociedade de Corte e do homem cortes.

Estudar a Sociedade de Corte, para Elias, é tão fundamental como estudar a sociedade feudal ou a cidade, sendo que as últimas já haviam sido objeto de vastos estudos. Do ponto de vista sociológico, o estudo da Sociedade de Corte requeria dar respostas para algumas perguntas:

Qual era a estrutura do campo social em cujo centro uma tal figuração podia ser construída? Qual era a distribuição de poderes, quais as exigências criadas socialmente, quais as relações de dependência em jogo para que os indivíduos desse campo social viessem a renovar ao longo de

Revista HISTEDBR On-line, Campinas, $n^{o}$ 53, p. 238-262, out2013-ISSN: 1676-2584 250 
gerações sucessivas essa figuração, convivendo na corte, numa sociedade de corte? Que exigências eram transmitidas, a partir da construção da sociedade de corte, para aqueles que desejavam prosperar ou apenas manter-se dentro dela? (ELIAS, 2001b, p. 61)

Para responder as questões levantadas, Elias recorre à própria história daquela figuração social; por isso, para ele, como vimos acima, há a necessidade de uma junção dos estudos sociológicos com os históricos. A importância de tal estudo, sociológico e histórico, reside no fato de que a Sociedade de Corte foi a instituição de maior significado central e representativo, como uma matriz de efeito mais abrangente, nos séculos XVII e XVIII, do que a cidade. A cidade, para o Ancien Régime, era apenas o "macaco" da corte. A vida política e econômica era delineada e decidida na corte e não na cidade. Sem um estudo aprofundado da formação e da caracterização da corte não é possível, para Elias, entender, em toda a sua extensão e qualidade, "a própria sociedade profissional-burguesaurbana-industrial" (ELIAS, 2001b, p. 65).

Ao se estudar a Sociedade de Corte, a primeira e principal indagação a ser feita, para Elias, é como se constituiu uma configuração de homens interdependentes que tornavam possível, e até aceitável, o seu governo centralizado nas mãos de um único homem. A resposta a esta pergunta passa pela compreensão de que o lento processo de transformação da vida feudal para a corte foi resultado de uma luta pelo monopólio do poder. A ideia de um senhor como centro político de uma organização foi construída no feudalismo, onde cada casa senhorial tinha o seu pequeno rei. A luta pela hegemonia dos poderes mais locais e, depois, regionais, era impulsionada pelo espirito guerreiro, até se chegar, no século XVII, ao monopólio de uma grande região, que passou a ser conhecida como o reino. Na testa do reino, o senhor de uma das principais casas, na luta pela hegemonia, passa ser o mandatário, passa a ser, de fato, o rei. Para se preservar no trono e preservar a unidade territorial o rei teve que submeter os senhores das outras casas, ou seja, o rei submeteu a sua própria classe de origem.

Segundo Elias nos apresenta, o aumento da quantidade de moedas em circulação nos reinos fez com que os preços aumentassem, e a nobreza empobrecesse devido o fato de que os aluguéis de suas terras eram fixos, e fez, também, com que a riqueza do rei aumentasse devido a arrecadação dos impostos. Essa foi uma das pré-condições para que a monarquia passasse a ter um caráter absoluto e ilimitado. Outra pré-condição deriva da primeira, a formação de um exército real que tornava o rei independente dos seus vassalos. A terceira pré-condição foi a transformação das técnicas militares. Em síntese, "Esse aumento das oportunidades de poder em mãos da função central constituía assim mais um condição prévia para a pacificação de um dado território, maior ou menor, conforme fosse o caso, a partir de um único centro" (ELIAS, 1994b, p. 21). Com a implantação do chamado absolutismo, definido dentre outras formas como "uma máquina de governo que forma o esqueleto dos estados modernos" (idem, p. 32), passa a haver uma relativa estabilidade da autoridade e das instituições centrais, especialmente se comparada com a instabilidade da autoridade central na fase anterior. Antes do absolutismo, argumenta Elias, o rei, e no caso exemplar do rei francês, não era natural, pois não passava do que o principal senhor de uma das principais casas senhoriais. Assim, se pensarmos o rei como sendo o soberano de uma região, cujo poder é centralizado, isso só acontece a partir do século XVI.

No processo que resultou na centralização política na figura do rei, o comportamento dos cavaleiros medievais teve que mudar. Donos de seus "reinos" particulares e, portanto, não necessitando ocultar ou reprimir emoções e sentimentos claros de distinção de classes, a partir do século XV os cavaleiros têm que transformar-se em Revista HISTEDBR On-line, Campinas, $n^{\circ}$ 53, p. 238-262, out2013-ISSN: 1676-2584 251 
cortesãos e nas "cortes semi-urbanas de príncipes e reis, forma-se uma nova aristocracia parcialmente com elementos da velha nobreza e em parte com novos elementos em ascensão, com um novo espaço social, novas funções e, em consequência, uma diferente estrutura emocional" (ELIAS, 1994a, p. 212). Os antigos senhores teriam que compreender, sob pena de serem condenados à morte, que "de senhores e cavaleiros livres, teriam que se transformar em servidores dependentes do rei” (idem, p. 213).

A corte era formada, basicamente, por três forças sociais, as quais tinham, também, suas esferas internas de disputa: o rei, a nobreza de sangue (noblesse d'épée) e a nobreza de toga (noblesse de robe). A nobreza de sangue era originária das antigas casas senhoriais e desenvolvia atividades mais diplomáticas e a nobreza de robe originava-se das altas camadas burguesas e tinha a seu cargo o funcionamento da máquina administrativa da Coroa. Havia um ethos diferenciado entre as duas nobrezas: na de robe a riqueza é particular e conseguida por meio da atividade laboral do comércio e nunca reinvestida totalmente na sociedade, pois uma parte era economizada, ou capitalizada, para aumentar sua própria riqueza; já na noblesse d'épée, a riqueza devia ser gasta inteiramente na sociedade naquilo que gerasse ou mantivesse o status correspondente. Esta nobreza não pode passar a impressão de parcimônia e moderação nos gastos, pois "alguém que não pode mostrar-se de acordo com seu nível perde o respeito da sociedade. Permanece atrás de seus concorrentes numa disputa incessante por status e prestígio, correndo o risco de ficar arruinado e ter de abandonar a esfera de convivência do grupo de pessoas de seu nível e status $9 "$ (ELIAS, 2001b, p. 86). No governo central francês, no século XVII, "a administração continuava a ser monopólio da burguesia" enquanto a corte tornava-se "monopólio dos nobres" (Idem, p. 167).

A corte era o palco das disputas entre as duas nobrezas, de desconfiança mútua e de acusações recíprocas. A luta pela hegemonia representava a luta por uma determinada visão de mundo e, por decorrência, uma determinada direção social. $\mathrm{O}$ rei atuava, afirma Elias, como mantenedor do equilíbrio entre as forças. Na Sociedade de Corte, como aliás em qualquer outra sociedade centralizada, havia a dependência do equilíbrio entre as forças antagônicas, onde o poder deveria estar tão uniformemente distribuído entre os grupos que não poderia "haver nem uma solução conciliatória decisiva", evitando-se a criação de uma identidade que colocasse em xeque a própria existência do poder central, e "nem um conflito decisivo entre eles" (ELIAS, 1994b, p. 148), que gerasse uma desestabilização total da sociedade. A função do rei era manter o equilíbrio entre "os grupos maiores e menores que se contrabalançavam como antagonistas interdependentes, simultaneamente como adversários e parceiros" (Idem). O rei atuava como o mediador de uma espécie de cabo de guerra (metáfora utilizada por Elias), tencionando a luta, não favorecendo nenhuma das partes, não se aproximando demasiado de nenhuma delas. Os favorecimentos e os desfavorecimentos eram medidos com exatidão, no caso exemplar da corte de Luis XIV, para não pender demais a balança para um dos lados.

A corte, no Ancien Régime, passa a ser local de residência dos nobres, especialmente da nobreza de sangue. O rei quer ter perto de seus olhos os representantes das forças sociais com as quais ele tem que conviver e manter em equilíbrio. Elias informa que em um relato de 1744 consta que o Palácio de Versalhes chegou a abrigar dez mil pessoas, as quais ou lá residiam ou para lá se dirigiam todos os dias (ELIAS, 2001b, p. 9899). O processo de dependência era relativo a todos, pois se os nobres dependiam do rei, dos seus favorecimentos, o rei passou a depender dos seus dependentes; uma rede de interdependências. Um exemplo tratado por Elias dessa dupla dependência recíproca é a etiqueta real. O levantar real, um dos vários momentos da etiqueta na corte, era um momento cercado de cerimônia em que estavam envolvidos, além é claro do rei, vários 
nobres que tinham as tarefas de preparar a roupa real, vestir o rei, preparar-lhe a mesa do café da manhã etc. Ser chamado para fazer parte de tal cerimônia era sinal de status e deixar de ser chamado para tal durante muito tempo era sinal contrário. Sem estardalhaços, sem mostrar irritação ou satisfação visíveis, o rei, no exemplo de Luís XIV, favorecia um, desfavorecia outro, pela presença ou não nos atos cerimoniais. No entanto, aponta Elias, apesar de ser o protagonista da etiqueta, o próprio rei a ela estava preso, sua vida era totalmente pública e, nesse sentido, acabava por ser, também ele, dominado.

É à etiqueta e ao cerimonial que todos os seus passos estão ligados [Luís XIV], e é através deles que, em meio à enorme afluência de pessoas, fica estabelecida com precisão a distância que ele precisa conservar em relação a elas, e vice-versa. Vistos assim, a etiqueta e o cerimonial são instrumentos de dominação, formas de expressar a coerção que o próprio poder exerce sobre o seu detentor. (ELIAS, 2001b, p. 152)

$\mathrm{Na}$ corte, o comportamento típico do cavaleiro, o espírito guerreiro, foi substituído pelo comportamento cortesão, próprio para a institucionalização da etiqueta real. A Sociedade de Corte desenvolve uma racionalidade diferente da época feudal, pois desenvolveu-se a consciência do controle das pulsões individuais e sociais, desenvolveu-se o controle do comportamento de acordo com o que se definia como emoções efêmeras por um lado e modelos conceituais duradouros por outro. Tal caráter específico dessa racionalidade deriva, "em primeiro lugar, do planejamento calculado da estratégia de comportamento em relação a possíveis perdas e ganhos de status e prestígio sob a pressão de uma competição contínua pelo poder" (ELIAS, 2001b, p. 110).

Um dos aspectos característicos da Sociedade de Corte é a arte de observar as pessoas. Era preciso uma observação atenta tanto dos outros como, também, de si mesmo, pois a "auto-observação e a observação das outras pessoas são correspondentes. Uma não teria sentido sem a outra" (ELIAS, 2001b, p. 121); sendo a auto-observação como uma disciplina para o convívio social. Nesse sentido, observa Elias, a noção de egoísmo como força motriz dos atos humanos se formou justamente na Sociedade de Corte e não, como normalmente se pensa, na sociedade capitalista.

Elias, se apoiando nas crônicas de La Bruyère ${ }^{10}$, usa a metáfora de um jogo de xadrez para definir a vida na corte. A espada, típica da vida cavalheirosa, é substituída, na corte, pela palavra, como arma para a intriga. Na vida cortesã, a "reflexão contínua, a capacidade de previsão, o cálculo, o autocrontrole, a regulação precisa e organizada das próprias emoções, o conhecimento do terreno, humano e não-humano, onde agia o indivíduo, tornaram-se precondições cada vez mais indispensáveis para o sucesso social" (ELIAS, 1994b, p. 226). Na corte, continua Elias, agora citando La Bruyere: "'homem que conhece a corte é senhor de seus gestos, de seus olhos e expressão. É um homem profundo, impenetrável. Dissimula as más ações que comete, sorri para os inimigos, reprime o malhumor, disfarça as paixões, rejeita o que quer o coração, age contra os sentimentos " (Idem).

$\mathrm{Na}$ sociedade cavalheirosa, tipicamente feudal, o conhecimento e o juízo (gostar/desgostar etc.) acerca das pessoas era basicamente motivado pela emoção, quase que de forma direta, pois não havia a necessidade de dissimulação; já na sociedade de corte, há o que Elias chama de psicologização da sociedade, pois há muito mais aspectos entre as pessoas do que antes e, portanto, a necessidade da observação, da análise profunda, de ver os sinais, de tentar enxergar além das aparências; na Sociedade de Corte há muito mais a dissimular. 
Um dos aspectos significativos na teoria de Norbert Elias sobre a construção e a configuração da Sociedade de Corte europeia, e consoante com a sua concepção da não separação entre indivíduo e sociedade, reside na necessidade de se compreender o processo histórico por dois ângulos que se tornam indispensavelmente complementares: o sociogenético e o psicogenético.

Desta forma, o processo sócio-histórico de séculos, no curso do qual o padrão do que é julgado vergonhoso e ofensivo e lentamente elevado, reencena-se em forma abreviada na vida do ser humano individual. Se quiséssemos expressar processos repetitivos desse tipo sob a forma de leis, poderíamos falar, como um paralelo às leis da biogênese, de uma lei fundamental de sociogênese e psicogênese. (ELIAS, 2001b, p. 129)

Com a sociogênese se investiga os aspectos sociais do surgimento e da construção de uma dada instituição, as relações de força, os determinantes econômicos, políticos e culturais que, numa visão de processo, contribuíram para a formatação final daquela configuração. Na formação da Sociedade de Corte, por exemplo, Elias mostra que a corte europeia do século XVI foi resultado de um grande processo de monopolização das grandes casas senhoriais, as quais, em meio às batalhas e à correspondente violência, disputava-se o poder pela hegemonia. O chefe das grandes casas assumem a função de soberano do território, com poder para tal e não apenas como uma quase figura de decoração como o rei feudal. A partir da conquista do monopólio se estabelece a corte como o espaço de atuação do rei, o qual passa a dirigir um equilíbrio, sempre precário, de forças opostas. O rei passa a dominar uma rede de interdependências e a corte se caracteriza como uma configuração social. "Apenas quando surge esse monopólio permanente da autoridade central, e o aparelho especializado para administração, é que esses domínios assumem o caráter de "Estado"” (ELIAS, 1994a, p. 98).

Já pelo estudo psicogenético da formação de uma instituição se estudam os elementos que fazem com que os indivíduos se tornem seus integrantes plenos, pela mudança no seu comportamento, pelo maior ou menor rigor nas atitudes e hábitos sociais. A mudança social acarreta uma mudança individual que lhe é correspondente e necessária, e é vista, também, em processo. A Sociedade de Corte caracterizou-se pela vida pública na corte real e, consequentemente, certas atitudes que existiam no espaço privado da casa deixaram de ser bem-vindas, e mais, algumas foram sendo execradas do convívio social. Pelo crescente aumento dos padrões de embaraço e vergonha, as pessoas na corte foram tendo um comportamento mais civilizado, em que a cortesia passou a ser a tônica. Aliás, a palavra corte designa tanto o espaço físico delimitado para os animais, isto é o curral, quanto a corte régia, no sentido estabelecido por Elias. Além disso, cortês e cortesia derivam de corte e referem-se as "boas maneiras" necessárias naquela configuração. As mudanças à mesa, na higiene pessoal, no trato entre as pessoas foram muitas e profundas durante o processo de formação e estabelecimento da Sociedade de Corte. Elias mostra, baseado em manuais de bom comportamento da época, muitos e muito difundidos, que certos comportamentos passam a ser tidos como rudes (cuspir no chão, por exemplo) e são deslocados da vida pública para a vida privada. Mas, tais mudanças no comportamento vão sendo introjetadas pela própria pessoa, que passa a desenvolver um superego que a policia e, ao mesmo tempo, naturaliza o controle das pulsões, controle esse necessário para que os comportamentos mudem de acordo com um novo padrão de relações no espaço público. Por exemplo: 
Nesse tempo, gradualmente, o costume, ora aceito como natural, de tomar sopa está sendo estabelecido: todos têm seu próprio prato e colher e a sopa é servida com um implemento especializado [a sopeira, na qual, antes, todos tomavam em conjunto]. $\mathrm{O}$ ato de comer adquiria um novo estilo, correspondendo às novas necessidades da vida social. (ELIAS, 2001, p. 112)

O problema teórico para Elias é estabelecer, com base em dados empíricos (documentos da época), a ligação entre as estruturas psicológicas individuais e as estruturas sociais, não as tomando como fixas, mas como mutáveis e interdependentes no desenvolvimento a longo prazo. Daí a necessidade de se realizar tanto um estudo sociogenético como um psicogenético da Sociedade de Corte.

Finalmente, o estudo da Sociedade de Corte requer, para Elias, o distanciamento comentado acima. Se um observador moderno olhar retrospectivamente a formação dos Estados Nacionais ele veria como natural o que foi resultado de uma longa luta que não tinha uma meta clara; fazendo isso, o observador pode, facilmente, julgar o passado pelos parâmetros do presente: "E exatamente como se os atores do passado já tivessem ante os olhos uma antevisão profética daquele futuro que para ele [o observador do presente] é tão evidente e, talvez, tão bem consolidado, louvaria ou condenaria esses atores, concederlhes-ia notas na medida em que seus atos levassem ou não ao trabalho almejado" (ELIAS, 1994b, p. 139). O presente condena, no passado, a violência; mas, como afirma Elias, sem a violência o processo civilizador não teria existido: "Sem ações violentas, sem as forças propulsoras da livre competição, não teria havido monopólio de força e, destarte, nenhuma pacificação, nenhuma supressão e controle da violência em grandes áreas." (Idem).

\section{Elias e a história da educação}

Nesta parte do artigo intencionamos estabelecer uma relação entre o pensamento de Norbert Elias e a Educação, particularmente a História da Educação. Como alertamos no início, é no mínimo precipitado considerá-lo como um intelectual da educação, pois ele, de fato, não se inscreve no campo específico das discussões educacionais, no entanto, é possível, a nosso ver, apoiarmo-nos em Elias para pensar a educação a partir de duas perspectivas: uma, interpretar como educacionais as mudanças que ele aponta no processo psicogenético da formação da Sociedade de Corte, e, outra, pensar na teoria elisiana como um suporte para compreendermos o fenômeno educativo.

Renato Janine Ribeiro, na apresentação que faz do volume primeiro d'O Processo Civilizador (1994a), afirma que o livro trata de como os homens se tornaram educados, de como começaram a tratar-se com boas maneiras, sendo, em síntese, um teoria sobre o desenvolvimento da civilização dos costumes, dos hábitos humanos, tanto individuais como sociais. Neste sentido, é possível afirmar que a história do processo civilizador europeu é, também, a história das mudanças educacionais por que passaram os homens, pois uma coisa é educar o homem guerreiro medieval e outra, bem diferente, é ensiná-los a se tornarem cortesãos.

A principal característica do homem da corte é, segundo, Elias, o controle das pulsões, ou seja, é o aprendizado do viver no espaço público e não mais no espaço privado e, portanto, a necessidade de introjetar comportamentos que passam a ser tidos como civilizados. A mudança de hábitos à mesa das refeições e no contato social entre as pessoas passou a ser uma necessidade e, por decorrência, quanto mais a mudança foi assumida como do indivíduo, naturalizada na pessoa, mais eficaz foi o processo civilizador. Elias recorre a vários manuais de civilidade produzidos entre os séculos XV e XVIII para, 
documentalmente, demonstrar como ocorreu tal processo de mudanças comportamentais e, dentre os manuais, o que mais recebeu destaque foi o de Erasmo de Roterdã, já acima citado.

A palavra civilidade adquiriu, com Erasmo, o status de palavra nova, ou palavra antiga mas com um novíssimo significado, o qual passou a ser usual em várias línguas. Elias aponta que palavras novas, quando incorporadas em uma sociedade, em uma língua, expressam mudanças na própria sociedade. A importância da obra de Erasmo reside menos no seu aspecto filosófico, ou como fenômeno literário, e mais como elevação da palavratítulo à condição de expressão fundamental de auto-interpretação da sociedade europeia. Não é o conteúdo em si, mas o que ele representa em termos de sociogênese e psicogênese que é fundamental na análise da obra de Erasmo e da sua importância para o processo civilizador do Ocidente.

$\mathrm{Na}$ obra de Erasmo há referências a atitudes e comportamentos estranhos aos nossos, que inclusive nos causam certo desconforto. No entanto, Elias chama a atenção para a historicidade da civilização, ou do comportamento dito civilizado, o qual ainda está (e continuamente) em construção ${ }^{11}$. Os manuais de boas maneiras, informa Elias, eram comuns na Idade Média, e foram divulgados em vários reinos, o que permite notar uma indicação geral de que os corteses, ou seja, os pertencentes à nobreza, deveriam ter comportamentos qualitativamente distintivos dos camponeses.

As mudanças no comportamento dos indivíduos foram lentas. Elias utiliza o exemplo do uso do garfo à mesa que, hoje tão natural para nós, demorou séculos até que passasse a compor os talheres utilizados no ato de se alimentar à mesa. Vejamos o exemplo como ilustrativo de inúmeras outras formas de comportamento que hoje são naturais, mas que, na verdade, são social e historicamente construídos.

Mais cinco séculos de passariam [a partir do século XI] antes que a
estrutura das relações humanas mudasse o suficiente para que o uso desse
utensílio [garfo] atendesse a uma necessidade mais geral. Do século XVI
em diante, pelo menos nas classes altas, o garfo passou a ser usado como
utensílio para comer, chegando através da Itália primeiramente à França
e, em seguida à Inglaterra e Alemanha, depois de ter servido durante
algum tempo apenas para retirar alimentos sólidos da travessa. [...] O que
achamos inteiramente natural, porque fomos adaptados e condicionados a
esse padrão social desde a mais tenra infância, teve, no início, que ser
lenta e laboriosamente adquirido e desenvolvido pela sociedade como um
todo. Isto não se aplica menos a uma coisa pequena e aparentemente
insignificante como um garfo do que as formas de comportamento que
nos parecem mais importantes. (ELIAS, 1994a, p. 78)

Voltando à importância da obra de Erasmo, Elias aponta que a diferença entre a sua obra e de outras escritas durante a Idade Média, é que a de Erasmo não é dirigida a uma classe de pessoas pois, mesmo ele fazendo distinção dos comportamentos rudes próprios da classe campesina, é a todos os homens da sociedade e não apenas aos nobres que há a prescrição de "regras humanas gerais" (ELIAS, 1994a, p. 88). No século XVI já há a consciência socialmente adquirida da necessidade de comportamentos mais civilizados, e não apenas relativamente ao comportamento à mesa, mas, também, à utilização de uma linguagem mais polida, o que, segundo Elias, passa a ser uma característica da sociedade francesa em geral no século XVIII.

Mas, o que condiciona a mudança no comportamento e na linguagem, ou seja, por que as pessoas passaram a ter boas maneiras e a falar com mais polidez no processo de 
formatação da Sociedade de Corte? Para Elias, três sentimentos estão envolvidos: o embaraço, a vergonha e o medo. De certa forma, tais sentimentos são os que guiam até hoje o processo de educação de nossas crianças.

O "patamar do embaraço" é o que Elias chama de motivador do processo de mudança que ocorre nos hábitos das pessoas. O que antes era tido como natural passa a ser repugnante e causa constrangimentos nas pessoas, especialmente no que diz respeito a comportamentos em público. No Ocidente, flatular e arrotar, por exemplo, passaram, num determinado momento, a embaraçar as pessoas, primeiramente no espaço público e, depois, mesmo no espaço privado. O "patamar do embaraço" ao avançar faz com que as pessoas sejam compulsadas a agir e falar de modo mais cortes. "Esta délicatesse, esta sensibilidade, e um sentimento altamente desenvolvido de embaraço, são no início aspectos característicos de pequenos círculos da corte e, depois, da sociedade de corte com um todo" (ELIAS, 1994a, p. 118). Depois de algum tempo, a sociedade cria explicações racionais para confirmar aquilo que já era resultado do embaraço e, com isso, a extensão de novos costumes passa para a sociedade toda.

O embaraço é a contrapartida inseparável da vergonha. O processo de mudança no comportamento civilizado do Ocidente, do espírito guerreiro para o cortes, foi motivado, também, pelo sentimento de vergonha, individual ou social, que limita consideravelmente as possibilidades individuais de ação.

O sentimento de vergonha é uma exaltação específica, uma espécie de ansiedade que automaticamente se reproduz na pessoa em certas ocasiões, por força do hábito. Considerado superficialmente, é um medo de degradação social ou, em termos mais gerais, de gestos de superioridade de outras pessoas. Mas é uma forma de desagrado ou medo que surge caracteristicamente nas ocasiões em que a pessoa que receia cair em uma situação de inferioridade não pode evitar esse perigo nem por meios físicos diretos nem por qualquer forma de ataque. [...] Nos adultos, porém, a impotência resultado do fato de que as pessoas cuja superioridade se teme estão de acordo com o próprio superego da pessoa, com a agência de autolimitação implantada no indivíduo por outros de quem ele foi dependente, que exerciam poder e possuíam superioridade sobre ele. De conformidade com isso, a ansiedade que denominamos "vergonha" é profundamente velada à vista dos outros. (ELIAS, 1994b, p. 242)

Por fim, Elias mostra que o sentimento do medo está umbilicalmente ligado aos sentimentos de vergonha e embaraço e, como estes, se encontra, primeiramente, no terreno da emoção para, depois, ter suas explicações racionais. Na Sociedade de Corte o medo agiu como estimulador do comportamento civilizado, como uma espécie de balizador dos hábitos e atitudes socialmente aceitos e os reprováveis. O maior medo, naquela sociedade, é o da desgraça social e, com tal motivação, a necessidade de comportamentos socialmente aceitáveis se naturalizou. No jogo da corte, que é o jogo do poder, o medo reprimia as atitudes intempestivas e compulsivas e instigava a observação, o refinamento das palavras, o fingimento, ou seja, a sobrevivência social.

Mas o medo, segundo Elias, não é necessariamente negativo, pois ele está na essência do homem como ser civilizado. O medo está na origem do controle dos comportamentos instintivos e está, também, na formação do superego, elementos fundantes do homem civilizado. 


\begin{abstract}
A criança e o adolescente jamais aprenderiam a controlar o próprio comportamento sem o medo instilado por outras pessoas. Sem a influência desses medos criados pelo homem, o jovem animal humano nunca se tornaria um adulto merecedor do nome de ser humano, tal como a humanidade de ninguém amadureceria plenamente se a vida lhe negasse suficientes alegrias e prazeres. Os medos que os adultos consciente ou inconscientemente inculcam na criança sofrem nela uma precipitação e, daí em diante, se reproduzem mais ou menos automaticamente. A personalidade maleável da criança é tão modelada por medos que ela aprende a agir de acordo com o padrão predominante de comportamento, sejam esses medos gerados pela força física direta ou pela privação, pela restrição de alimento ou prazeres. Os medos e ansiedades criados pelo homem, sejam eles medos ao que vem de fora ou ao que está dentro de nós, finalmente mantêm em seu poder até mesmo o adulto. A vergonha, o medo da guerra e o medo de Deus, o medo que o homem sente de si mesmo, de ser dominado pelos seus próprios impulsos afetivos, todos eles são direta ou indiretamente induzidos nele por outras pessoas. Sua força, forma e o papel que desempenham na personalidade do indivíduo dependem da estrutura da sociedade e de seu destino nela. (ELIAS, 1994b, p. 269-270)
\end{abstract}

A criança, na sociedade moderna, especialmente na atualidade, deve em poucos anos, aprender a ter nojo e repugnância de certos comportamentos. Aversão esta que a sociedade levou séculos para desenvolver. Nesse processo, o embaraço, a vergonha e o medo são sentimentos fundamentais que modelarão e introjetarão na criança comportamentos socialmente aceitos; forma-se o superego em meio ao que não se pode fazer. A pressão pela civilidade das crianças, anota Elias, não vêm somente dos pais, mas é "sempre a sociedade como um todo [família, escola, igreja etc.], todo o conjunto dos seres humanos, que exerce pressão sobre a nova geração, levando-a mais perfeitamente, ou menos, para seus fins" (ELIAS, 1994a, p. 145).

A criança é educada a se tornar um ser civilizado. No processo de mudança e de adequação há sempre um conflito entre as pulsões e os seus controles. $\mathrm{O}$ ego do indivíduo se forma, na sociedade moderna, oriunda da Sociedade de Corte, entre o desejo e a inibição, entre o id e o superego. A busca ideal para a formação do indivíduo saudável e, por consequência, a construção de uma relação social igualmente salutar, se encontra na busca do equilíbrio, pois não há, anota Elias, nem id em seu estado puro e nem superego que aja plenamente; a falta do equilíbrio gera problemas mentais graves com repercussões sociais problemáticas. O que importa, portanto, na formação do indivíduo, o que determina a conduta "são os equilíbrios e os conflitos entre as pulsões maleáveis e os controles constituídos sobre as pulsões" (ELIAS, 1994b, p. 238).

Antes de terminar esta parte sobre as possibilidades da utilização de Elias no campo da História da Educação, para além da discussão que ele estabelece relativa à formação/educação do homem moderno, cremos ser oportuno apresentar algumas indicações bibliográficas de autores que se apoiam nos aportes teóricos de Elias para suas pesquisas educacionais. Há inúmeras pessoas pesquisando a teoria elisiana em si e relacionando-a a vários aspectos da sociedade e em várias ciências, como História, Sociologia, Antropologia, Filosofia, Psicologia e, mesmo, na Educação.

Os autores que citamos a seguir compõem uma pequena amostra e que, para os leitores que desejarem, podem servir para momentos de aprofundamentos teóricos: $\operatorname{Costa}^{12}, \operatorname{Costa}^{13}$, Gebara $^{14}$, Honorato $^{15}, \operatorname{Krotsch}^{16}$, Leão $^{17}$, Miranda $^{18}$, Sarat $^{19}$, Simões $^{20}$, Teive $^{21}$ e Veiga $^{22}$. 
Finalizando...

Findamos este artigo, que se propõe a ser introdutório ao pensamento de Norbert Elias, indicando dois breves momentos de sua vida e teoria que, a nosso ver, demonstram as suas qualidades enquanto pesquisador e a atualidade do seu pensamento. Pedimos licença para, inusualmente do que se espera para o momento de finalização dos trabalhos acadêmicos, novamente fazermos algumas citações de Elias, por considerarmos que, neste momento, a interpretação pode ficar mais pobre que o original.

$\mathrm{O}$ primeiro momento refere-se às suas memórias, em que Elias faz um balanço da sua trajetória como pesquisador:

Recentemente - e isso me irritou muito - li num estudo inglês que eu era
o último representante da sociologia clássica, alguém que aspira à grande
síntese, e assim por diante. Isso me irritou porque preferiria ser o
primeiro a abrir um novo caminho. Sempre fiquei espantado ao ver o
número de pessoas que perdem a coragem em nossos dias, como se nada
mais valesse a pena ser feito; há tantas coisas a fazer, e há tanta gente
fazendo qualquer coisa ou que se corrompeu intelectualmente. Minha
experiência é que vou vendo pouco a pouco alguma coisa de novo, e
assim dou um exemplo: pode-se fazê-lo, e isso vale a pena. Acho essa
falta de coragem, esse niilismo e essas lamentações absolutamente
insuportáveis. (ELIAS, 2001a, p. 84 )

Ter contato com a teoria dos processos civilizadores de Norbert Elias é adentrar em algo complexo, que precisa ser lido e relido com alguns cuidados. A possibilidade de enquadrá-lo em alguma teoria antecessora à sua existe, pois Elias é um homem do seu tempo e, de certa forma, herdeiro das suas tradições. No entanto, cremos que o melhor caminho para o conhecimento de sua teoria é encará-la como uma tentativa de realmente fazer algo novo, algo inédito, e daí tirar toda possibilidade de contarmos com um aporte teórico sólido para nossas pesquisas.

O segundo momento, também de suas memórias, refere-se ao seu lado docente. Perguntado por que não teve filhos e se não lamentava não ter sido pai, Elias (2001a, p. 86), respondeu: "Não, não seriamente. Quero dizer que sempre apreciei dar aulas para estudantes e, se quiserem, podem chamar isso de um substituto. O ensino tem alguma coisa de paternal".

Diziam os antigos que "quem conta um conto, acrescenta um ponto". Temos clareza que o pensamento de Norbert Elias tratado aqui é fruto da nossa interpretação e, portanto, corre o risco de ser parcial. Assim, terminamos este texto sugerindo aos seus leitores desejosos e/ou curiosos de se aprofundar na teoria elisiana que, em primeiro lugar, leiam diretamente os seus livros, tanto os que aqui foram objeto de apresentação como os outros por ele escritos e, além disso, entrem em contato com uma bibliografia sobre o pensamento de Elias, para o que sugerimos alguns autores: Alain e Lacroix ${ }^{23}$, Brandão ${ }^{24}$, Gebara, Pilatti e Wouters $^{25}$, Heinich ${ }^{26}$, Leão ${ }^{27}$, Sarat e Santos $^{28}$, Souza, Simões e Lucena ${ }^{29}$, e Waizbort ${ }^{30}$. 


\section{Referências}

EPICURO. Carta sobre a felicidade (a Meneceu). São Paulo: Editora Unesp, 2002.

FREUD, S. O mal-estar na civilização. IN: Obras Completas. Vol. XVIII. Rio de Janeiro: Imago, 1996a.

GIRALDI, R. OMS: Doenças mentais e neurológicas atingem cerca de 700 milhões de pessoas, alerta OMS. Agência Brasil. http://agenciabrasil.ebc.com.br/noticia/2013-0520/oms-doencas-mentais-e-neurologicas-atingem-cerca-de-700-milhoes-de-pessoas-alertaoms, de 20.05.2013, consulta realizada em 01 out 2013.

ELIAS, N. O Processo Civilizador. Uma história dos costumes. Vol. 1. Rio de Janeiro: Zahar, 1994a.

O Processo Civilizador. Formação do Estado e civilização. Vol. 2. Rio de Janeiro: Zahar, 1994b.

. Norbert Elias por ele mesmo. Rio de Janeiro: Zahar, 2001a.

. A Sociedade de Corte. Rio de Janeiro: Zahar, 2001b.

Sobre os seres humanos e suas emoções: um ensaio sob a perspectiva da sociologia dos processos. In: GEBARA, A.; WOUTERS, C. (orgs.). O controle das emoções. João Pessoa: Editora da UFPB, 2009.

\section{Notas}

${ }^{1}$ Professor do Departamento de Fundamentos da Educação e do Programa de Pós-Graduação em Educação da Universidade Estadual de Maringá. Líder do grupo de pesquisa Laboratório de Estudos do Império Português (LEIP/UEM).

${ }^{2}$ Professor do Departamento de História e do Programa de Pós-Graduação em História da Universidade Estadual de Maringá. Líder do grupo de pesquisa Laboratório de Estudos do Império Português (LEIP/UEM).

${ }^{3}$ Para Elias, a crítica que Mannheim fez de construções intelectuais como ideologias e, portanto, como construções comprometidas com doutrinas, parou do meio do caminho: "Mas deteve-se [Mannheim] nesse nível. Não podia - nem queria, provavelmente - ir além de uma simples análise crítica que desmascarasse a construção intelectual de outros indivíduos e a fizesse aparecer como ideologia; contentava-se com sua relativização e sua destruição" (ELIAS, 2001a, p. 122)

${ }^{4}$ Talcott Parsons, sociólogo funcionalista norteamericano, que viveu entre 1902 e 1979.

${ }^{5}$ Um exemplo do problemático julgamento do passado pelo presente pode ser buscado no primeiro volume d'O processo Civilizador, quando Elias mostra que no decorrer da constituição da Sociedade de Corte a violência foi sendo relegada para outros patamares da sociedade. Era próprio do espírito guerreiro do homem feudal a exposição da violência física, sendo isso naturalizado naquela relação social. No espírito do homem cortesão a violência física não era mais o recurso primeiro (talvez o último) para solucionar as disputas. Mas, como a exposição da violência não deixa de fazer parte do habitus social de uma hora para outra, no século XVI teve início uma festa, na França, a festa de São João, que era a queima de gatos, na qual capturavam-se os animais, colocando-os em sacos sobre uma fogueira. $\mathrm{O}$ asco que é produzido no leitor/pesquisador da atualidade pode levar a um julgamento daquela sociedade como plena de crueldade. Elias procura mostrar, no exemplo, que "a queima de gatos no Dia de São João era um costume social, como o boxe ou a corrida de cavalos na sociedade moderna" (p. 201) e, mais do que isso, representou um avanço no patamar da civilização no que se refere à violência. A violência do passado julgada pelos olhos atuais acarreta a condenação moral do passado; vista pela ótica da sua época e relacionando-a com períodos anteriores podese ver, inclusive, avanços sociais muito importantes. 


\begin{abstract}
${ }^{6}$ Epicuro, na sua Carta sobre a felicidade (2002, p. 33), afirma que "Nunca devemos nos esquecer de que o futuro não é nem totalmente nosso, nem totalmente não nosso, para não sermos obrigados a esperá-lo como se estivesse por vir com toda a certeza, nem nos desesperarmos como se não estivesse por vir jamais".

${ }^{7}$ Freud, em $O$ mal-estar na civilização (1996, p. 95) afirma: “Assim, nossas possibilidades de felicidade sempre são restringidas por nossa própria constituição. Já a infelicidade é muito menos difícil de experimentar. O sofrimento nos ameaça a partir de três direções: de nosso próprio corpo, condenado à decadência e à dissolução, e que nem mesmo pode dispensar o sofrimento e a ansiedade como sinais de advertência; do mundo externo, que pode voltar-se contra nós com forças de destruição esmagadoras e impiedosas; e, finalmente, de nossos relacionamentos com os outros homens. O sofrimento que provém dessa última fonte talvez nos seja mais penoso do que qualquer outro. Tendemos a encará-lo como uma espécie de acréscimo gratuito, embora ele não possa ser menos fatidicamente inevitável do que o sofrimento oriundo de outras fontes."
\end{abstract}

${ }^{8}$ Ao que parece, a época de Elias ainda não apresentava as doenças mentais, como a depressão, como um sintoma social grave. No entanto, estudos recentes da Organização Mundial da Saúde apontam dados preocupantes nesta direção: "As doenças mentais e neurológicas atingem aproximadamente 700 milhões de pessoas no mundo, representando um terço do total de casos de doenças não transmissíveis, segundo a Organização Mundial da Saúde (OMS). Os especialistas advertem que pelo menos um terço dos que sofrem com problemas mentais e neurológicos não tem acompanhamento médico. A revelação está no Plano de Ação para a Saúde Mental 2013-2020. [...].[o qual] mostra que as doenças mentais representam 13\% do total de todas as doenças do mundo e são um terço das patologias não transmissíveis. Segundo as estimativas, cerca de 350 milhões de pessoas deverão sofrer de depressão e 90 milhões terão uma desordem pelo abuso ou dependência de substâncias. A OMS define depressão como um transtorno mental comum, caracterizado por tristeza, perda de interesse, ausência de prazer, oscilações entre sentimentos de culpa e baixa autoestima, além de distúrbios do sono ou do apetite. Também há a sensação de cansaço e falta de concentração. A depressão pode ser de longa duração ou recorrente. Na sua forma mais grave, pode levar ao suicídio. Casos de depressão leve podem ser tratados sem medicamentos, mas, na forma moderada ou grave, as pessoas precisam de medicação e tratamentos profissionais." (GIRALDI, 2013)

${ }^{9}$ O romance $O$ Leopardo (1958), de Giuseppe Tomasi di Lampedusa, é um interessante exemplo da diferença dos dois tipos de ethos e da convivência e luta entre eles, ao mostrar a derrocada da aristocracia siciliana e da formação da nova burguesia no periodo da unificação da Itália em 1870. O romance virou filme com o mesmo título, dirigo por Luchino Visconti (1963).

${ }^{10}$ Jean de la Bruyère (1645-1696), moralista francês, escreveu Les Caractères ou les Mcurs de ce siècle (Personagens ou costumes do século) (1688), que é uma crônica da vida no século XVII.

${ }^{11}$ Tomemos como exemplo atual o comportamento dos fumantes. Até poucos anos atrás, era permitido, ou melhor, praticamente não se questionava o ato de fumar em lugares públicos, como salas de aula, restaurantes e ônibus. Hoje em dia tais locais são impensáveis para a prática do tabagismo. Não somente as leis, mais as regras sociais, das quais as leis são expressão, relegaram o ato de fumar para lugares abertos. Os fumantes, de forma geral, introjetaram tal comportamento e eles mesmos não se vêem mais fumando em lugares públicos.

${ }^{12}$ COSTA, C. J. O Rei D. João III (1521-1557) e a construção da sociedade de corte em Portugal. http://www.uel.br/grupo-

estudo/processoscivilizadores/portugues/sitesanais/anais14/arquivos/textos/Mesa_Coordenada/Trabalhos_Co mpletos/Celio_Juvenal_Costa.pdf

13 COSTA, M. R. da. Infância, educação e processos culturais: um estudo a partir da sociologia configuracional de Norbert Elias In: $3^{\circ}$ Seminário Brasileiro de Estudos Culturais e Educação, 2008, Canoas. $3^{\circ}$ Seminário Brasileiro de Estudos Culturais e Educação: Pedagogias sem fronteiras. Canoas: ULBRA, 2008.

${ }^{14}$ GEBARA, A. Anotações para a teoria do Progresso Civilizador: proposições para a História da Educação. Comunicações (Piracicaba), Piracicaba, v. 5, n. 2, p. 140-151, 1998. E, GEBARA, A. Educação e Lazer na Teoria do Processo Civilizador: primeiros contatos entre portugueses e brasileiros. Revista Historiografia Brasileira Contemporânea, Unicentro/Guarapuava, v. 2, p. 134-144, 2004.

${ }^{15}$ HONORATO, T. Elementos para uma história do poder na instituição escolar no esforço civilizador brasileiro. In: XVII Encontro Regional de História - O historiador e seu tempo, 2006, Assis/SP. O historiador e seu tempo - ANPUH/SP/2006. Assis/SP : UNESP, 2006. v. 01. 
${ }^{16}$ KROTSCH, L. Esbozo de un proceso civilizador argentino a través de la escuela pública. Estado, nación y educación pública en la segunda mitad del Siglo XIX. http://www.uel.br/grupoestudo/processoscivilizadores/portugues/sitesanais/anais14/arquivos/textos/Mesa_Coordenada/Trabalhos_Co mpletos/Lucas_Krotsch.pdf

${ }^{17}$ LEAO, A. B. Ler, Obedecer, Instruir-se: uma pedagogia analítica da alma feminina. Educação em Debate, Fortaleza, v. 1, p. 38-47, 2002. E, LEAO, A. B. Publicar contos de fadas na Velha República, um compromisso com a nação - Revista do curso de Gestão da Comunicação - Ano XII - N.3 Set/dez 2007 USP -ECA- CCA - Paulinas. Comunicação \& Educação, v. 1, p. 15-22, 2007.

${ }^{18}$ MIRANDA, L. F. A. de. A razão ilustrada e a diversidade humana. Educação e Sociedade, São Paulo; Campinas, v. 27, n. n. 95, p. 341-360, 2006.

${ }^{19}$ SARAT, M. A Infância e a Formação Civilizada do Indivíduo em Norbert Elias. http://www.uel.br/grupoestudo/processoscivilizadores/portugues/sitesanais/anais14/arquivos/textos/Mesa_Coordenada/Trabalhos_Co mpletos/Magda_Sarat.pdf. E, SARAT, M. A infância no Brasil do século XIX: percepções dos viajantes na literatura de viagem. Revista Educação e Fronteiras, v. 01, p. 85-103, 2007. E, ainda, SARAT, M. Crianças brasileiras no século XIX: mal educadas, mal criadas ou (des)civilizadas. Revista Conexões Educação Esporte E Lazer, Campinas-SP, v. 05, p. 59-67, 2000.

${ }^{20}$ SIMÕES, J. L. Educação para as elites, escola para os vadios e violência para todos. Dialogia (Uninove), v. 05, p. 93-100, 2006.

${ }^{21}$ TEIVE, G. M. G. Civilização e Progresso: O papel da Escola Normal Catarinense no projeto de modernização do Estado de Santa Catarina na década de 1910. http://www.uel.br/grupoestudo/processoscivilizadores/portugues/sitesanais/anais14/arquivos/textos/Mesa_Coordenada/Resumos_Exp andidos/Gladys_Teive.pdf

${ }^{22}$ VEIGA, C. G. A produção da infância nas operações escriturísticas da administração da instrução elementar no século XIX. Revista Brasileira de História da Educação, São Paulo, v. 9, p. 73-108, 2005.E, VEIGA, C. G. Escola de alma branca: o direito biológico à educação no movimento da Escola Nova. Educação em Revista (UFMG), Belo Horizonte, MG, n. especial, p. 123-150, 2000. E, ainda, VEIGA, C. G. Escola Pública para os negros e os pobres no Brasil: uma invenção imperial. Revista Brasileira de Educação, v. 13, p. 502-517, 2008.

${ }^{23}$ ALAIN, G.; LACROIX, B. Norbert Elias a Política e a História. São Paulo: Perspectiva, 2001.

${ }^{24}$ BRANDÃO, C. da F. Norbert Elias: formação, educação e emoções no processo de civilização. Petrópolis: Vozes, 2003. E, BRANDÃO, C. da F. Os processos de civilização e o controle das emoções. Florianópolis: Edusc, 2008.

${ }^{25}$ GEBARA, A. Conversas sobre Norbert Elias: depoimentos para uma historia do pensamento sociológico. Piracicaba: Biscalchin Editor, 2005. E, GEBARA, A.; PILATTI, L. A. Ensaios sobre História e Sociologia nos esportes. Jundiaí: Fontoura, 2006. E, ainda, GEBARA, A.; WOUTERS, C. (orgs). O controle das emoções. João Pessoa: Editora Universitária da UFPB, 2009.

${ }^{26}$ HEINICH, N. A Sociologia de Norbert Elias. Florianópolis: Edusc, 2001.

${ }^{27}$ LEAO, A. B. Norbert Elias \& a Educação. Editora: AUTENTICA Assunto: Educação-leitura Idioma: Português Ano: 2007

${ }^{28}$ SARAT, M.; SANTOS, R. dos (orgs.). Sobre Processos Civilizadores: diálogos com Norbert Elias. Dourados: UFGD, 2012.

${ }^{29}$ SOUZA, E. F. de; SIMÕES, J. L.; LUCENA, R. de F. (orgs). Escritos a partir de Norbert Elias. Recife: Editora Universitária da UFPE, 2009.

${ }^{30}$ WAIZBORT, L. (org). Dossiê Norbert Elias. São Paulo: Edusp, 2009.

Recebido em outubro-13

Aprovado em novembro-13 